\title{
EFEKTYWNOŚĆ MEDIACJI W POSTĘPOWANIU ADMINISTRACYJNYM
}

Standard społeczeństwa obywatelskiego oznacza partycypację obywateli $\mathrm{w}$ bezpośrednich procesach decyzyjnych $\mathrm{w}$ sprawach uwidaczniających interesy i dążenia obywateli ${ }^{1}$. Instytucja mediacji $\mathrm{w}$ sprawie administracyjnej jest instrumentem prawnym, czyli środkiem służącym osiągnięciu określonego celu, jakim jest polubowne załatwienie sprawy². Taki charakter tejże instytucji podkreślają normy Kodeksu postępowania administracyjnego ${ }^{3}$. Jej zaletami są przede wszystkim zaangażowanie w jego przebieg różnych grup zainteresowanych, formowanie płaszczyzny współpracy między jednostką a administracją - tym samym może się przyczyniać do zwiększania efektywności postępowania, czyli realizacji motywów wprowadzenia mediacji do K.p.a. w związku z podstawowymi zasadami postępowania administracyjnego takimi jak: szybkość

* Dr hab., Katolicki Uniwersytet Lubelski Jana Pawła II; e-mail: valter@kul.pl, ORCID ID: https:/ / orcid.org/0000-0002-1303-6737.

1 Zob. K. Ostaszewski, Partycypacja społeczna w procesie podejmowania rozstrzygnięć w administracji publicznej, Lublin 2013.

2 Według L. Morawskiego rozwój alternatywnych metod rozwiązywania sporów (dalej: ADR) stanowi „jedno z najważniejszych przedsięwzięć, które zmierzają do przystosowania wymiaru sprawiedliwości do realiów społeczeństw postindustrialnych, a zwłaszcza do dokonujących się [...] procesów funkcjonalnej i kulturowej dyferencjacji systemów społecznych. Postulat alternatywnych form wymiaru sprawiedliwości to zatem istotne uzupełnienie programu postklasycznej teorii procesu, która powinna sobie zdawać sprawę z tego, że postulatu organizacji nowoczesnego wymiaru sprawiedliwości nie można oprzeć wyłącznie na procesach sądowych", L. Morawski, Główne problemy wspótczesnej filozofii prawa. Prawo w toku przemian, Warszawa 2005, s. 188.

3 Ustawa z dnia 14 czerwca 1960 r. - Kodeks postępowania administracyjnego, tekst jednolity: Dz. U. z 2018 r. poz. 2096 (dalej: K.p.a.). 
postępowania (art. 12 K.p.a.), zasada zaufania obywateli do organu (art. 8 K.p.a.) i zasady polubownego rozwiązywania sporów (art.13 K.p.a.). $\mathrm{W}$ niniejszym opracowaniu zostanie najpierw przedstawione uzasadnienie wprowadzenia mediacji do K.p.a., a następnie jej istota i zasady, zakres zastosowania mediacji oraz wnioski w kontekście efektywności postępowania administracyjnego.

\section{Uzasadnienie wprowadzenia mediacji do K.p.a.}

Mediacja to niekonfrontacyjny sposób doprowadzenia do załatwienia sprawy przy udziale profesjonalnego, bezstronnego, neutralnego podmiotu (mediatora). Stanowi istotne novum ${ }^{4} \mathrm{w}$ polskiej regulacji postępowania administracyjnego ${ }^{5}$. Wprawdzie instytucja ta funkcjonuje od dnia 1 stycznia 2004 r. w postępowaniu przed sądami administracyjnymi, ale nie była dotychczas uregulowana w treści przepisów K.p.a. ${ }^{6}$ Ponadto zmiany zachodzące $\mathrm{w}$ administracji publicznej w epoce

4 Nowelizacją Kodeksu postępowania administracyjnego dokonano zmian znacząco wpływających na kształt procedury administracyjnej i sądowoadministracyjnej. Nowe przepisy ustawy weszły w życie dnia 1 czerwca 2017 r. Zgodnie z założeniami nowelizacji wprowadzane zmiany mają służyć usprawnieniu procedur administracyjnych i sądowoadministracyjnych oraz zminimalizowaniu biurokracji i zmodyfikowaniu modelu władczego podejścia administracji w stosunku do obywatela. Wprowadzone instrumenty mają przyczynić się do rozwoju partnerskich relacji między administracją publiczną a obywatelem przy wykorzystaniu polubownych metod rozstrzygania sporów i załatwiania spraw $\mathrm{w}$ trybie koncyliacyjnym.

5 Instytucja mediacji w postępowaniu administracyjnym została wprowadzona w niektórych regulacjach obcych w sposób bezpośredni, czyli w ustawie procesowej, bądź pośredni - w ogólnej ustawie o mediacji. Przykładowo, od 2005 r. instytucja ta jest obecna w szwajcarskiej federalnej ustawie o postępowaniu mediacyjnym (Bundesgesetz über das Verwaltungsverfahren - Verwaltungsverfahrensgesetz, Art. 33b Hter. Gütliche Einigung und Mediation). Mediację przewiduje również przepis art. L 421-1 Francuskiego Code des relations entre le public et l'administration z dnia 25 października 2015 r. Wreszcie instytucję reguluje kanon 1733 § 1 Kodeksu Prawa Kanonicznego z 1983 r. Zob. J. Wegner-Kowalska, Idea mediacji w postępowaniu administracyjnym, Przegląd Prawa Publicznego 2016, nr 10, s. 93-98.

6 Zob. A. Jakubowski, w: Kodeks Postępowania Administracyjnego. Komentarz, red. M. Wierzbowski, A. Wiktorowska, wyd. 28, 2019 [baza danych Beck Online Komentarze], Art. 96 K.p.a. 
innowacyjnych przemian społecznych i technologicznych w sektorze publicznym znacząco wpływają na modyfikację relacji administracjaobywatel. Konieczne staje się tworzenie partnerskich relacji między administracją a obywatelem ${ }^{7}$.

W uzasadnieniu do rządowego projektu ustawy o zmianie ustawy Kodeks postępowania administracyjnego ${ }^{8}$ oraz niektórych innych ustaw wraz z projektami aktów wykonawczych jako pierwszą przyczynę nowelizacji wskazano przewlekłość prowadzonych postępowań, którą K.p.a. definiuje jako stan, w którym postępowanie jest prowadzone dłużej niż jest to niezbędne do załatwienia sprawy ${ }^{9}$. Zwrócono przede wszystkim uwagę na podmioty prowadzące działalność gospodarczą, które przez przewlekłe działanie organu dotyczące np. wydania koncesji, zezwolenia lub decyzji odnoszących się do procesu inwestycyjnego, nie są w stanie $\mathrm{w}$ przewidzianym przez siebie terminie wykonywać zamierzonych działań. Zauważono, że przedsiębiorca nie może przewidzieć, w jakim terminie zostanie załatwiona jego sprawa, z uwagi na to, że instrukcyjne terminy wynikające $z$ kodeksu są często nierespektowanie przez organ. Na nieprzewidywalność wpływa też fakt, iż organy administracji

7 W dobie ówczesnych społecznych i ekonomicznych przemian administracja publiczna stoi przed ogromnymi wyzwaniami. Postępująca globalizacja, rozwój nowych technologii i rosnąca świadomość społeczeństwa informacyjnego, stały się przyczyną wprowadzanych innowacji do sektora publicznego. Obecnie podkreśla się znaczenie mechanizmów służących doskonaleniu usług publicznych zwiększających wydajność oraz podwyższających ich jakość. Kształtuje się de facto nowy model zarządzania instytucją publiczną i kultura nowego zarządzania publicznego (New Public Management). Realizacja założeń nowego modelu pozwala wpłynąć na skuteczniejszą realizację zadań i czyni administrację bardziej przyjazną obywatelom. Zob. U. Kobylińska, Innowacje w administracji publicznej w Polsce na poziomie samorzadu lokalnego, Prace Naukowe Uniwersytetu Ekonomicznego we Wrocławiu 2015, nr 402: Polityka ekonomiczna, s. 142-152; M. Kulesza, D. Sześciło, Polityka administracyjna i zarządzanie publiczne, Warszawa 2013, s. 67; J. Supernat, Administracja publiczna, "governance" i nowe publiczne zarzadzanie, w: Prawna działalność instytucji społeczeństwa obywatelskiego, red. J. Blicharz, J. Boć, Wrocław 2009, s. 139-146; Z. Kmieciak, Problemy i wyzwania partycypacji w postępowaniu administracyjnym, w: Partycypacja w postępowaniu administracyjnym. W kierunku uspołecznienia interesu prawnego, red. Z. Kmieciak, Warszawa 2017, s. 17-45.

8 Rządowy projekt ustawy o zmianie ustawy - Kodeks postępowania administracyjnego oraz niektórych innych ustaw wraz z projektami aktów wykonawczych z dnia 28 grudnia 2016 r., Druk nr 1183, Uzasadnienie, s. 3-5, https://www.sejm.gov.pl/Sejm8. nsf/druk.xsp?nr=1183 [dostęp: 15.09.2019 r.].

9 Zob. art. 37 § 1 pkt. 2 K.p.a. 
publicznej nie są związane praktyką stosowania prawa, którą stosowały dotychczas. Strony nie mają zatem pewności co do orzeczenia, jakie zostanie wydane przez organ, nawet jeśli w analogicznych sprawach zapadały już decyzje $\mathrm{e}^{10}$.

Kolejną przyczyną wskazaną w uzasadnieniu był brak w przepisach mechanizmów umożliwiających stronom wzięcie czynnego udziału $\mathrm{w}$ decydowaniu o treści rozstrzygnięcia organu. Staje się to przyczyną nieusatysfakcjonowania stron podjętym rozstrzygnięciem. Strony wnoszą środki zaskarżenia od decyzji, a co za tym idzie, postępowanie ulega wydłużeniu. Dalej, jako źródło problemów w postępowaniu administracyjnym, które były bodźcem do wprowadzenia nowych instytucji do K.p.a., została wymieniona "piętrowość” procedur administracyjnych. Określenie to odnosi się do konieczności odwołania się od decyzji przed zaskarżeniem jej do sądu administracyjnego, który to uchylając zaskarżoną decyzję ponownie pozostawia rozstrzygnięcie sprawy organowi administracji ${ }^{11}$.

Wśród przyczyn nowelizacji wymieniono również zbyt częste występowanie decyzji kasatoryjnych, nieklarowna i nieefektywna regulacja dotycząca środków zaskarżenia uchybień w trybie administracyjnym, nadmierny formalizm i rygorystyczne postrzeganie władczości. Czynniki te wpływają na nierealizowanie kodeksowych zasad zaufania obywateli do organów państwa i zasady przekonywania ${ }^{12}$. Wszystkie wyżej

10 Polska Agencja Rozwoju Przedsiębiorczości przeprowadziła badanie wśród przedsiębiorców, z którego wynika, że 78,1\% respondentów zauważa problem przewlekłości postępowania przed organami administracji. Za realnością tego problemu przemawiają statystyki prowadzone przez NSA, według których liczba skarg wniesionych na bezczynność i przewlekłość wyniosła w 2014 r. - 6769 (z czego uwzględniono 2199), w 2015 r. - 6517 (uwzględniono 1893), w 2016 r. - 6597 (uwzględniono 2137), w 2017 r. - 6305 (uwzględniono 1735) oraz w 2018 r. - 5716 (uwzględniono 2220) skarg, http:/ /www.nsa.gov.pl/ statystyki-wsa.php [dostęp: 10.06.2019 r.].

11 O powszechności zaskarżania decyzji do wojewódzkich sądów administracyjnych świadczą dane, według których w 2014 r. do WSA wpłynęło 77393 skarg, z czego 16592 zostały uwzględnione, w 2015 r. - 77 012, (uwzględniono 16 504), w 2016 r. - 70095 (uwzględniono 14 340), w 2017 r. - 66121 (uwzględniono 15 850) oraz w 2018 r. - 60247 skarg, z czego 15601 uwzględnionych. Tak więc, na przestrzeni ostatnich pięciu lat średnio 22\% skarg zostaje uwzględnionych, http:// www.nsa.gov.pl/statystyki-wsa.php [dostęp: 10.06.2019 r.].

12 Zob. art. 8 i art. 11 K.p.a. 
wymienione czynniki wpływają na ocenę administracji publicznej przez obywateli i poziom ich zaufania do państwa ${ }^{13}$.

Wprowadzenie instytucji mediacji do polskiego K.p.a. stanowi również realizację rekomendacji Komitetu Ministrów Rady Europy z dnia 5 września 2001 r. Rec(2001)9 o alternatywnych środkach rozstrzygania sporów sądowych między władzami administracyjnymi, a osobami (stronami) prywatnymi, w której wskazano mediację jako środek pozwalający na załatwienie sprawy administracyjnej ${ }^{14}$. W dokumencie tym podkreślono także prewencyjną rolę mediacji, umożliwiającą ograniczenie liczby spraw rozpoznawanych przez sądy administracyjne ${ }^{15}$.

\section{Istota i zasady mediacji w K.p.a.}

Mediacja stanowi wyraz kształtowania stosunków prawnych nie tylko z aktywnym, ale także i partycypacyjnym udziałem stron postępowania. Artykuł 13 K.p.a. nakłada na organ administracji obowiązek dążenia do rozwiązywania kwestii spornych oraz ustalenia praw i obowiązków stron postępowania we wszystkich sprawach, których charakter na to pozwala. Skorzystanie przez stronę z takiego działania administracji jest jej

13 W badaniach przeprowadzonych w 2018 r. przez Centrum Badania Opinii Społecznej tylko 54\% respondentów zadeklarowało zaufanie do urzędników administracji publicznej, lepiej wypadły władze lokalne miast i gmin, do których zaufanie zadeklarowało 65\% badanych, https://www.cbos.pl/SPISKOM.POL/2018/K_035_18.PDF [dostęp: 10.06.2019 r.].

${ }_{14}$ Council of Europe Committee of Ministers, Recommendation Rec2001(9) of the Committee of Ministers to member states on alternatives to litigation between administrative authorities and private parties (Adopted by the Committee of Ministers on 5 September 2001 at the $762^{\text {nd }}$ meeting of the Ministers' Deputies), https://search.coe.int/cm/Pages/result_details. aspx?ObjectId=09000016805e2b59 [dostęp: 15.09.2019 r.]; tekst polski: Mediacja w sprawach administracyjnych, red. H. Machińska, Warszawa 2007, s. 109-113.

15 Zob. Z. Kmieciak, Mediacja i koncyliacja w prawie administracyjnym, [Kraków] 2004, s. 133. Dodatkową motywacją wprowadzenia przepisów o mediacji były pozytywne wnioski płynące z doświadczeń m.in. słoweńskich, hiszpańskich, brytyjskich, niemieckich $\mathrm{w}$ zakresie stosowania polubownych metod rozwiązywania sporów w postępowaniach administracyjnych, zob. J. Wegner-Kowalska, Mediacja (art. 13, art. 96a-96g), w: Raport Zespołu Eksperckiego z prac w latach 2012-2016. Reforma prawa o postępowaniu administracyjnym, red. Z. Kmieciak, Warszawa 2017, s. 73-75; W. Federczyk, Mediacje w sferze działania władz publicznych - doświadczenia niemieckie, ADR Arbitraż i Mediacja 2012, nr 2, s. 103-115. 
uprawnieniem - nie obowiązkiem. Istotą tej zasady jest prawo stron postępowania do wzięcia udziału w kreowaniu rozstrzygnięcia sprawy.

Cel i warunki prowadzenia mediacji zakreśla art. 96a § 3 K.p.a.: „Celem mediacji jest wyjaśnienie i rozważenie okoliczności faktycznych i prawnych sprawy oraz dokonanie ustaleń dotyczących jej załatwienia w granicach obowiązującego prawa, w tym przez wydanie decyzji lub zawarcie ugody". Wprowadzana regulacja zakłada dopuszczalność mediacji zarówno pomiędzy stronami postępowania, jak i pomiędzy stronami a organem administracji publicznej, przed którym sprawa się toczy (art. 96a § 4 K.p.a.). Polubowne zakończenie sprawy, co do której organ administracji i strona zajmują odmienne stanowiska (mediacja $\mathrm{w}$ relacji wertykalnej), jak i takiej, w której strony postępowania dążą do rozwiązania kwestii spornych (mediacja w relacji horyzontalnej) - może zapobiec wszczęciu postępowania odwoławczego czy sądowoadministracyjnego, skoro poprzez wspólne wypracowywanie rozwiązań przez strony lub stronę i organ, adresat rozstrzygnięcia zyskuje poczucie, że miał na nie realny wpływ, co więcej - zgodził się na nie. To znacząco wpływa na jej zadowolenie z finalnego efektu postępowania.

W doktrynie nie wykształcił się jednolity katalog zasad odnoszących się do postępowania mediacyjnego. Wśród najczęściej wymienianych są zasady: dobrowolności, bezstronności i neutralności, poufności. Zasady te zostały również zawarte $\mathrm{w}$ przepisach regulujących instytucję mediacji w K.p.a. Artykuł 96a § 2 K.p.a. stanowi, że mediacja jest dobrowolna. Warunkiem dopuszczalności mediacji jest zgoda strony na jej przeprowadzenie rozumiana nie tylko jako zaaprobowanie przeprowadzenia tego procesu, ale również jako wola polubownego załatwienia sprawy czy dążenia do rozstrzygnięcia kwestii spornych ${ }^{16}$. Do przeprowadzenia mediacji potrzebna jest zgoda wszystkich uczestników. Nie można jej domniemywać, a brak złożenia oświadczenia woli dotyczącego zgody na przeprowadzenie mediacji wyklucza możliwość jej przeprowadzenia. Uprawnienie to rozciąga się na całe postępowanie mediacyjne, więc strona w każdym czasie jego trwania może bez konsekwencji z niego zrezygnować ${ }^{17}$. Ponadto zasada dobrowolności mediacji odnosi się zarówno do

16 Zob. P. Przybysz, w: Kodeks postępowania administracyjnego. Komentarz, red. P. Przybysz, Warszawa 2017, s. 341-342.

17 Zob. R. Morek, Dobrowolność mediacji i jej ograniczenia (prawo i praktyka), Studia Iuridica 2008, t. 49, s. 156. 
strony postępowania, jak i do organu administracji publicznej ${ }^{18}$, czyli do każdego z rodzajowo oznaczonych uczestników mediacji ${ }^{19}$.

Chociaż w kodeksie nie zostało to uregulowane wprost, zasadę dobrowolności należy odnieść także do osoby mediatora. Wprawdzie w przepisach nie znajdują się zapisy odnośnie do ewentualnej odmowy przeprowadzenia mediacji lub zrezygnowania z jej prowadzenia już $w$ trakcie, to jednak należy przyjąć, że mediatorowi przysługuje takie prawo ${ }^{20}$.

Wyrazem realizacji jednego z podstawowych założeń instytucji mediacji, czyli pośredniczenia w wypracowaniu wspólnego stanowiska między uczestnikami mediacji, jest bezstronność osoby mediatora. Zasada bezstronności w K.p.a. jest analogiczna do uregulowania tej kwestii w Kodeksie postępowania cywilnego ${ }^{21}$. Bezpośrednie odwołanie $\mathrm{w}$ art. $96 \mathrm{~g}$ $\S 1$ K.p.a. do przepisu, który reguluje wyłączenie pracownika organu od załatwienia sprawy wskazuje, że bezstronność mediatora polega na braku jego powiązania z uczestnikami mediacji i braku interesu w załatwieniu w określony sposób sprawy będącej przedmiotem mediacji. Odwołanie do art. 24 § 1 i 2 K.p.a. nie wyczerpuje okoliczności świadczących o braku bezstronności mediatora. Przykładowo za takie okoliczności można również uznać powiązania towarzyskie czy zawodowe mediatora. Jak wskazuje kodeks, nie trzeba udowadniać, że zachodzą ww. okoliczności, a wystarczą jedynie wątpliwości co do wystąpienia braku bezstronności. Okoliczności te mogą istnieć już przed przystąpieniem do mediacji lub pojawić się dopiero po jej rozpoczęciu. Ustawową gwarancją bezstronności jest zakaz pełnienia funkcji mediatora przez pracownika organu administracji publicznej, przed którym toczy się postępowanie w sprawie (art. $96 f$ § 3 K.p.a.).

18 Dobrowolność mediacji $\mathrm{w}$ odniesieniu do organu administracji publicznej jest względna - kryterium ograniczającym jest regulacja art. $13 \S 1$ pkt 2 oraz $\S 2$ K.p.a. Niewyrażenie przez organ zgody na udział w mediacji jest możliwe, ale nie może godzić w istotę regulacji art. 13 K.p.a. Jak wskazał WSA w Krakowie w związku z nieprzeprowadzeniem mediacji nie można zarzucić organowi naruszenia prawa, ponieważ jej przeprowadzenie nie jest obowiązkowe, zob. wyrok WSA w Krakowie z dnia 26 kwietnia 2018 r., II SA/Kr 323/18, LEX nr 2471986.

19 Zob. A. Kocot-Łaszczyca, G. Łaszczyca, Mediacja w ogólnym postępowaniu administracyjnym, Warszawa 2018, s. 43.

20 Zob. M. Wilbrandt-Gotowicz, w: Kodeks postępowania administracyjnego. Komentarz, red. M. Jaśkowska, A. Wróbel, Warszawa 2018, s. 598-600.

${ }^{21}$ Ustawa z dnia 17 listopada 1964 r. - Kodeks postępowania cywilnego, tekst jednolity: Dz. U. z 2019 r. poz. 1460 z późn. zm. (dalej: K.p.c.). 
Bezstronność mediatora musi występować w parze z jego neutralnością. Neutralność to stosunek mediatora do przedmiotu sporu, sytuacji konfliktowej i propozycji jej rozwiązania. Mediator nie może patrzeć na daną sprawę przez pryzmat swoich poglądów, nie powinien identyfikować się z żądną stroną oraz popierać jej stanowiska ${ }^{22}$. Odzwierciedlenie tej zasady powinno być widoczne także w samym przebiegu postępowania mediacyjnego. Mediator nie powinien proponować rozwiązań kwestii spornych w sposób odzwierciedlający interes tylko jednej strony, czyniąc to kosztem innych uczestników. Mediator powinien zapewnić uczestnikom mediacji porównywalny udział w mediacji poprzez możliwość zaprezentowania swojego stanowiska czy też propozycji odnośnie do rozwiązania sprawy ${ }^{23}$. Ustawa nakłada na mediatora obowiązek odmowy przeprowadzenia mediacji i zawiadomienia uczestników mediacji oraz organu w razie uznania, że zachodzą wątpliwości odnośnie do jego bezstronności. Zawiadomienie takie ma charakter wiążący dla organu. W ustawie brak jest natomiast regulacji pozwalającej na zmianę mediatora w przypadku, gdyby strona chciała podnieść zarzut jego bezstronności ${ }^{24}$.

Jedną z największych zalet mediacji jest poufność wpisana w istotę tej instytucji. Stanowi proceduralnoprawną zasadę i wymaga realizacji poprzez ustanowienie stosownych środków jej ochrony oraz procesowych gwarancji ${ }^{25}$. Poufność rozciąga się na cały przebieg mediacji niezależnie od tego, czy w jej wyniku dojdzie do ugody. Odnosi się ona zarówno do posiedzeń z obiema stronami, jak i indywidualnych spotkań mediatora ze stroną $^{26}$. U podstaw wyłączenia jawności leży konieczność zapewnienia uczestnikom mediacji swobody wyrażania opinii, która jest bardzo istotna w kontekście osiągnięcia celów mediacji. W związku z tym ujawnione powinny być tylko ustalenia, które znalazły odzwierciedlenie w protokole mediacji. Precyzyjnie reguluje to art. 96j § 3 K.p.a. stanowiący, że po zakończeniu mediacji, z wyjątkiem ustaleń, które znalazły się w protokole, nie mogą być wykorzystywane propozycje ugodowe, złożone w toku

22 Zob. P. Przybysz, w: Kodeks postępowania administracyjnego..., s. 346-347.

23 Zob. M. Wilbrandt-Gotowicz, w: Kodeks postępowania administracyjnego..., s. 628-629.

24 Zob.J.Wegner, w: Kodeks postępowania administracyjnego. Komentarz, red. W. Chróścielewski, Z. Kmieciak, 2018 [baza danych LEX], Komentarz do art. 96f K.p.a.

${ }_{25}$ Zob. R. Kędziora, Kodeks postępowania administracyjnego. Komentarz, Warszawa 2017, s. 568.

26 Zob. P. Waszkiewicz, Zasady mediacji, w: Mediacje. Teoria i praktyka, red. E. Gmurzyńska, R. Morek, Warszawa 2009, s. 100-103. 
mediacji oświadczenia oraz ujawnione fakty. Obowiązek zachowania zasady poufności rozciąga się na mediatora, uczestników mediacji, organ administracji (o ile bierze udział w mediacji) oraz inne uczestniczące w niej osoby. Jedną z gwarancji zrealizowania zasady poufności przez mediatora jest zakaz dowodowy z przesłuchania go w charakterze świadka odnośnie do faktów, o których dowiedział się w związku z przeprowadzeniem mediacji (art. $83 \S 4$ K.p.a.). Zarówno mediator, uczestnicy, jak i inne osoby biorące udział mogą zostać zwolnione z obowiązku tajemnicy mediacji przez zgodną wolę jej uczestników ${ }^{27}$. Zgoda taka powinna być do celów dowodowych wyrażona na piśmie. Ustawa nie zakreśla temporalnej granicy trwania wyłączenia jawności, więc co do zasady trwa ona także po zakończeniu mediacji ${ }^{28}$. W K.p.a., podobnie jak w uregulowaniu mediacji w K.p.c., nie określono konsekwencji naruszenia zasady poufności. Należy zatem przyjąć, że takie naruszenie będzie rodziło odpowiedzialność odszkodowawczą na podstawie art. 415 K.p.c. ${ }^{29}$

27 Odmienne stanowisko prezentuje J. Wegner, zdaniem której prawo do zwolnienia $\mathrm{z}$ tajemnicy przysługuje temu uczestnikowi, który ujawnia w mediacji określone fakty. Uczestnik ten ma możliwość określenia zakresu zwolnienia, zob. J. Wegner, w: Kodeks postępowania administracyjnego..., 2018 [baza danych LEX], Komentarz do art. 96j K.p.a.

28 Zob. M. Wilbrandt-Gotowicz, w: Kodeks postępowania administracyjnego..., s. 628-629.

29 Zob. P. Przybysz, w: Kodeks postępowania administracyjnego..., s. 349-350. Agnieszka Kocot-Łaszczyca i G. Łaszczyca w swoim opracowaniu wskazują jeszcze zasady elastyczności, szybkości oraz protokolarności. Ta pierwsza bywa nazywana zasadą ograniczonego formalizmu. W K.p.a. nie znalazły się prawne reguły dotyczące prowadzenia mediacji. Poza uregulowaniem osoby mediatora jako podmiotu prowadzącego mediację oraz przepisami regulującymi spisanie protokołu, mediacja nie ma przewidzianej kodeksowo formy. Po części jej przebieg wynika z przepisów regulujących rolę mediatora, jednak czynniki takie jak forma, miejsce, czas i porządek posiedzenia oraz inne kwestie techniczne postępowania mediacyjnego pozostają w gestii mediatora i uczestników. Kolejną zasadą jest zasada szybkości. Nie wynika ona wprost z przepisu, ale można ją wyprowadzić z ogólnej zasady szybkości postępowania uregulowanej w art. 12 § 1 i art. 2 K.p.a., z przepisu ograniczającego termin wyrażenia zgody na przeprowadzenie mediacji oraz art. 96e $\S 1$ i 2 K.p.a. Realizacja zasady szybkości przejawia się w wyznaczeniu czasu trwania mediacji z uwzględnieniem wielu czynników takich jak charakter sprawy, zaangażowanie uczestników, rodzaju uczestników w granicach przewidzianych prawem. Jako ostatnia została wymieniona zasada protokolarności. Wynika ona zarówno z ogólnej zasady pisemności postępowania jak i z art. 96m § 1 K.p.a., który reguluje kwestie związane z protokołem. Obowiązek sporządzenia protokołu, przedłożenia go organowi oraz doręczenia odpisów uczestnikom spoczywa na mediatorze. Elementy prawidłowo sporządzonego protokołu zostały unormowane w art. $96 \mathrm{~m} \S 2$ K.p.a. Pomimo tego, ze kodeks nie reguluje 


\section{Zakres zastosowania mediacji}

Instytucji mediacji w postępowaniu administracyjnym służy rozszerzenie zakresu zasady polubownego rozstrzygania kwestii spornych wyrażone w art. 13 K.p.a. Mediacja ma być realizowana zarówno jako metoda działania organu, jak i sposób wypracowywania rozstrzygnięcia sprawy. Taki kształt przepisu powinien tym bardziej skłaniać organy administracji do mediowania spraw, które się do tego nadają.

Artykuł 13 K.p.a. zawiera dwie zasady określające granicę czynności, jakie organ może podejmować dążąc do realizacji zasady koncyliacyjności. Pierwszą z nich jest zasada, która ogranicza ww. obowiązek do spraw, których charakter na to pozwala. Określenie czy powyższe kryterium jest spełnione, wymaga oceny konkretnej sprawy nie tylko pod kątem materialnoprawnym czy procesowym, ale także z uwzględnieniem subiektywnego spojrzenia na dany problem przez pryzmat możliwości i celowości przeprowadzenia prób polubownego rozwiązania sprawy ${ }^{30}$. Oceny tej kwestii dokonuje organ administracji publicznej prowadzący postępowanie w sprawie.

Druga zasada określa charakter podejmowanych czynności, stanowiąc, że czynności podejmowane przez organ muszą być uzasadnione na danym etapie postępowania. Wyszczególnione zostały czynności informacyjne o możliwościach i korzyściach polubownego załatwiania sprawy, lecz nie jest to katalog zamknięty. Kryterium etapu nie odnosi się do wyodrębnionego $\mathrm{w}$ procesie stadium postępowania, ale zostało użyte w znaczeniu fragmentu, w jakim obecnie znajduje się postępowanie. Kryterium to wskazuje na konieczność analizy powzięcia ewentualnych działań w kontekście całego postępowania. Szerokie ujęcie czynności, które ma za zadanie podejmować organ, zostało jednak zawężone w stosunku do mediacji, ograniczając powinność organu do powzięcia czynności „niezbędnych do przeprowadzenia mediacji"31.

Zakres zastosowania mediacji w postępowaniu administracyjnym determinuje art. 96a K.p.a. Ustanawia on pozytywną przesłankę

szczególnych cech protokołu, jako dokument urzędowy powinien on spełniać cechy takie jak m.in. prawdziwość, staranność, dokładność, zwięzłość, zob. A. Kocot-Łaszczyca, G. Łaszczyca, Mediacja w ogólnym postępowaniu..., s. 121-125.

30 Zob. Z. Kmieciak, w: Kodeks postepowania administracyjnego. Komentarz, red. W. Chróścielewski, Z. Kmieciak, 2018 [baza danych LEX], Komentarz do art. 13 K.p.a.

31 A. Kocot-Łaszczyca, G. Łaszczyca, Mediacja w ogólnym postępowaniu..., s. 22-23. 
dopuszczalności przeprowadzenia mediacji. W $§ 1$ tegoż artykułu w sposób nieostry został określony zakres spraw, w których możliwe jest przeprowadzenie mediacji. Użyte sformułowanie: ,jeżeli pozwala na to charakter sprawy" stanowi powtórzenie treści art. 13 § 1 K.p.a. stanowiącego o ogólnej zasadzie polubownego załatwiania spraw. Takie sformułowanie przesłanki nakazuje twierdzić, że katalog takich spraw jest ograniczony. Ustawodawca nie wyznaczył jednak precyzyjnych kryteriów, w odniesieniu do których należy ocenić sprawę w kontekście możliwości przeprowadzenia mediacji, co może nasuwać wątpliwości interpretacyjne. Poza tym należy pamiętać, że o ile na gruncie etymologicznym pojęcie mediacji nierozerwalnie łączy się ze sporem, to inaczej jest w postępowaniu administracyjnym, w którym do przeprowadzenia mediacji nie jest konieczne zaistnienie sporu. Wynika to zarówno z treści art. 13 K.p.a., który dążenia do polubownego załatwienia spraw nie zawęża do kwestii spornych, ale odnosi do spraw będących przedmiotem postępowania. Ponadto samo występowanie spornych interesów nie przesądza o dopuszczalności mediacji. O charakterze sprawy w kontekście mediacji decyduje przede wszystkim charakter przedmiotu postępowania w postaci uprawnienia lub obowiązku. By przeprowadzenie mediacji było dopuszczalne musi istnieć możliwość elastycznego ukształtowania pewnych elementów rozstrzygnięcia, dotyczących między innymi sposobu wykonywania, treści czy granic czasowych uprawnienia lub obowiązku ${ }^{32}$.

Według M. Sieniuć, sprawa posiada charakter mediacyjny wtedy, gdy przepisy prawa publicznego zawierają regulacje pozwalające na załatwienie sprawy $w$ granicach uznania administracyjnego. Można zatem wnioskować, że im większy jest zakres swobody decyzyjnej organu administracji, tym większa jest zdolność mediacyjna sprawy i szanse na powodzenie mediacji. Natomiast w przypadku spraw rozstrzyganych w drodze decyzji związanych, owo „związanie” nie daje swobody decyzyjnej organowi. Wówczas negocjacje uczestników mediacji mogą dotyczyć takich kwestii jak np. termin wykonania obowiązku przez stronę $e^{33}$.

Pomimo tego, iż w K.p.a. nie wymieniono negatywnych przesłanek dotyczących charakteru spraw, od których zależy możliwość przeprowadzenia mediacji, należy przyjąć, że zachodzą również przesłanki

32 Zob. tamże, s. 63-77.

33 Zob. M. Sieniuć, w: Prawo procesowe administracyjne, red. R. Hauser, Z. Niewiadomski, A. Wróbel, System Prawa Administracyjnego 9, Warszawa 2017, s. 249. 
negatywne uniemożliwiające jej przeprowadzenie. Przede wszystkim są to sprawy, w których zachodzi stan wyższej konieczności, czyli sytuacja w której sprawa wymaga szybkiego rozstrzygnięcia z uwagi na konieczność pilnego zabezpieczenia jakiegoś dobra. W szczególności są to sprawy, w których decyzji można nadać rygor natychmiastowej wykonalności lub podlega ona takiemu wykonaniu ex lege. Skierowanie takiej sprawy do mediacji - a co za tym idzie odroczenie jej rozstrzygnięcia - uniemożliwiałoby sprawne wydanie decyzji. Za kolejną negatywną przesłankę należy uznać kryterium prostoty postępowania, której K.p.a. nadaje moc zasady ogólnej. Artykuł 12 K.p.a. in fine stanowi, że organy administracji publicznej powinny działać w sprawie możliwie najprostszymi środkami do jej załatwienia. Mediacji nie powinno się więc przeprowadzać w sprawach, w których osiągnięcie jej celów można uzyskać przy pomocy innych, mniej złożonych środków. Podobnie w postępowaniu załatwianym $\mathrm{w}$ trybie uproszczonym mediacja zdaje się być niedopuszczalna. Przymioty związane z postępowaniem uproszczonym, takie jak zakres podmiotowy zasadniczo dotyczący interesu lub obowiązku jednej strony, wykorzystywanie urzędowych formularzy w postępowaniu, ograniczone postępowanie dowodowe i inne, wyłączają możliwość przeprowadzenia mediacji w toku takiego postępowania. Z uwagi zarówno na właściwości samego trybu, jak i terminy, postępowanie mediacyjne jest też wykluczone w przypadku spraw załatwianych w drodze instytucji milczącego załatwienia sprawy. Jako ostatnie negatywne kryterium uznano postępowania, w których zachodzi obowiązek ochrony przez organ administracji publicznej tajemnicy zawodowej lub informacji niejawnych. Jeżeli w przepisie szczególnym nie zostało uregulowane udostępnianie takich informacji mediatorowi, wówczas nie mogą mu one zostać udostępnione. Przeprowadzenie więc takiej mediacji byłoby niecelowe, $\mathrm{z}$ uwagi na brak wiedzy mediatora o informacjach istotnych w sprawie ${ }^{34}$.

Agnieszka Kocot-Łaszczyca i G. Łaszczyca omawiając przesłanki dopuszczalności postępowania mediacyjnego, utworzyli swoisty katalog spraw o potencjale mediacyjnym. Znalazły się w nim sprawy, w których obowiązek lub uprawnienie może być ukształtowane za pomocą uznania administracyjnego. Uprawnienie to wynika bezpośrednio z ustawy. Przejawia się najczęściej w sformułowaniu „organ może” i jest ograniczone przez szereg zasad wykształconych przez naukę prawa - między innymi

34 Zob. A. Kocot-Łaszczyca, G. Łaszczyca, Mediacja wo ogólnym postępowaniu..., s. 77-83. 
zasada działania $\mathrm{w}$ interesie publicznym. Kolejna kategoria to sprawy, w których treść, sposób wykonania i inne elementy obowiązku lub uprawnienia organ administracji publicznej może elastycznie kształtować. Dotyczy to zwłaszcza takich elementów decyzji jak sposób korzystania, stawiane wymagania czy też zasady udostępniania. W ostatniej grupie zostały wyodrębnione uprawnienia i obowiązki, których treść oraz elementy dodatkowe można określić jako podzielne. Wyżej wymienione kryteria mogą występować łącznie. Określając czy dana sprawa może być przedmiotem mediacji zawsze należy najpierw określić jaki charakter obowiązku lub uprawnienia wynika z przepisów prawa materialnego. Mediacja nie może jednak służyć określeniu przez uczestników mediacji, na mocy własnych ustaleń, stanu faktycznego w sprawie ${ }^{35}$. Ponadto w uzasadnieniu projektu ustawy o zmianie ustawy - Kodeks postępowania administracyjnego wskazano, że mediacja może mieć charakter prewencyjny, czyli może pozwolić na uniknięcie skierowania sprawy do sądu administracyjnego poprzez wyjaśnienie przesłanek podstawy prawnej rozstrzygnięcia ${ }^{36}$. Przyjęcie takiego stanowiska stałoby jednak w sprzeczności z ustawowymi celami mediacji. Poza tym w postępowaniu administracyjnym cel informacyjny można osiągnąć środkami prostszymi niż mediacja ${ }^{37}$.

W praktyce, mediacja może być przydatna w sposób szczególny w sprawach, w których: strony mają sporne interesy, występuje konflikt interesu społecznego z interesem indywidualnym strony, organ administracji publicznej działa $\mathrm{w}$ ramach uznania administracyjnego, występuje wiele stron, istnieją trudności w skutecznej komunikacji ze stroną albo stronami, może być zawarta ugoda administracyjna, organ ma zamiar wydać decyzję na niekorzyść adresata i może się spodziewać odwołania, czy wreszcie kiedy został wniesiony środek odwoławczy od orzeczenia wydanego w pierwszej instancji. Natomiast z uwagi na przedmiot sprawy, to w sprawach związanych z procesem inwestycyjnym, np. ustalenie warunków zabudowy, ustalenie uwarunkowań środowiskowych, pozwolenia na budowę, sporami sąsiedzkimi, np. rozgraniczenia nieruchomości, a także z działalnością regulowaną.

35 Zob. art. 7 K.p.a.

36 Zob. Rządowy projekt ustawy o zmianie ustawy - Kodeks postępowania administracyjnego oraz niektórych innych ustaw wraz z projektami aktów wykonawczych z dnia 28 grudnia 2016 r., Druk nr 1183, Uzasadnienie, s. 37.

37 Zob. A. Kocot-Łaszczyca, G. Łaszczyca, Mediacja w ogólnym postępowaniu..., s. 70-77. 


\section{Wnioski dotyczące wpływu sposobu regulacji instytucji mediacji w K.p.a. na efektywność postępowania administracyjnego}

Wśród zalet mediacji w postępowaniu administracyjnym należy wymienić: kształtowanie dobrych relacji pomiędzy administracją publiczną i społeczeństwem, szybkość postępowania i zakończenia sprawy, szansa na uniknięcie postępowania odwoławczego lub sądowoadministracyjnego, poufny charakter, efektywna komunikacja pomiędzy stronami dzięki wsparciu dobrego mediatora, niższe koszty, a także łatwość przedstawiania dowodów. Mediacja z istoty swej powinna zatem pozytywnie wpływać na efektywność postępowania administracyjnego. W praktyce instytucja ta wciąż jednak nie cieszy się popularnością.

Jednym z celów wprowadzenia mediacji do K.p.a. - co zaakcentowano w uzasadnieniu ustawy nowelizującej - jest zbliżenie administracji do społeczeństwa, kształtowanie stosunków administracyjnoprawnych w sposób umożliwiający stronom postępowania większy wpływ na swoje sprawy, a także sprawy istotne dla społeczeństwa. Sformułowano również pogląd, że mediacja jest możliwa nie tyle pod warunkiem uprzedniej modernizacji administracji publicznej, ale jako jeden ze sposobów dokonywania zmian kultury administrowania na bardziej przyjazny dla petentó $w^{38}$. Podstawowym atrybutem administracji publicznej jest władztwo administracyjne. Przejawia się ono koniecznością podporządkowania jednostki aktom administracyjnym ${ }^{39}$. Natomiast mediacja uregulowana w K.p.a. daje duży zakres swobody osobom zainteresowanym jej przeprowadzeniem, w tym co do kształtowania jej zasad, sposobu procedowania, czy w końcu ponoszenia kosztów za jej przeprowadzenie. Szereg przepisów ma tutaj charakter semiimperatywny i stwarza warunki do elastycznego funkcjonowania mediacji. $Z$ jednej strony jest to czynnik zwiększający efektywność postępowania administracyjnego, a z drugiej strony bardzo wiele zależy przede wszystkim od praktyki, jaka się kształtuje w związku z nową regulacją oraz umiejętności prowadzenia mediacji przez mediatoró $w^{40}$.

38 Zob. tamże, s. 16.

39 Zob. B. Sitek, Jednostka wobec władztwa administracyjnego. Studium prawno-historyczno-porównawcze, w: Jednostka wobec dziatań administracji publicznej, red. E. Ura, E. Feret, S. Pieprzny, Rzeszów 2016, s. 28.

40 Zob. J. Wegner-Kowalska, Mediacja..., s. 78. 
Mediacja w K.p.a. jest realizacją zasady sprawiedliwości proceduralnej i wyrazem zasady dobra wspólnego. Jest ona również realizacją zasady subsydiarności nakazującej wykonywanie zadań publicznych blisko obywatela. Bez wątpienia korzystanie przez administrację publiczną z mechanizmów komunikacyjnych - mediacji - powinno umożliwić realizację potrzeb obywateli ${ }^{41}$. Z drugiej strony, wzrost partycypacji nie może być traktowany jednostronnie - jako jedynie szansa. Wprowadzenie szerszego udziału podmiotów zewnętrznych w decydowaniu administracyjnym, generuje jednocześnie także szereg nowych problemów i wyzwań związanych z partycypacją, która to ma również swoje wewnętrzne ograniczenia ${ }^{42}$. Wydaje się, że administracja publiczna nie jest wciąż dostatecznie na to wyzwanie przygotowana. Należy również zwrócić uwagę na wciąż kształtującą się i rozwijającą kulturę prawną społeczeństwa i tym samym niekiedy na brak rozumienia instytucji mediacji przez obywateli, co może przekładać się, z jednej strony, na brak zainteresowania udziałem w takim postępowaniu lub próbę nieuzasadnionego jej nadużywania, z drugiej. Podkreślić również należy mentalność i dotychczasową praktykę orzeczniczą sprawowaną przez urzędników przywiązanych do sformalizowanych procedur.

Na szczególną uwagę zasługuje kwestia terminów związanych z przeprowadzeniem mediacji. Już na etapie prac nad ustawą podnoszono, że mediacja może być wykorzystywana jako instrument służący do przedłużenia postępowania. Zwracano uwagę również na terminy, które w przypadku mediacji mogą prowadzić do odroczenia wydania rozstrzygnięcia w postępowaniu administracyjnym na aż trzy miesiące, co wydaje się nie korespondować z zasadą szybkości postępowania.

Zgodnie z art. 96n § 1 K.p.a., jeżeli w wyniku mediacji zostaną dokonane ustalenia dotyczące załatwienia sprawy w granicach obowiązującego prawa, organ administracji publicznej załatwia sprawę $w$ oparciu o ustalenia zawarte $\mathrm{w}$ protokole $\mathrm{z}$ przebiegu mediacji. Wytyczne co do treści protokołu zostały określone w art. 96m $§ 2$ K.p.a. Organ jest związany ustaleniami zamieszczonymi $\mathrm{w}$ protokole mediacji, tylko $\mathrm{w}$ granicach

${ }^{41}$ Zob. M. Tabernacka, Mediacje w postępowaniu administracyjnym: uwarunkowania aksjologiczne i prakseologiczne, Kontrola Państwowa 2018, nr 3, s. 87.

42 Zob. M. Stępień, Janusowy charakter partycypacji w decydowaniu administracyjnym, w: Partycypacja w postępowaniu administracyjnym. W kierunku uspołecznienia interesu prawnego, red. Z. Kmieciak, Warszawa 2017, s. 257-258. 
obowiązującego prawa. Dotyczy to nie tylko przepisów K.p.a., ale całego systemu prawa. Aby zagwarantować zgodność z prawem, organ administracji musi zatwierdzić ugodę zawartą przed mediatorem. Będzie oczywiście musiał tego odmówić, jeżeli ugoda została zawarta z naruszeniem prawa. Konieczność ta wynikać będzie z odesłania zawartego w przepisie art. 121a K.p.a., zgodnie z którym do ugody zawartej przed mediatorem stosuje się odpowiednio przepisy dotyczące ugody zawartej przed organem administracji, wyrażone $\mathrm{w}$ art. 117-121 K.p.a. Zawarcie ugody nie jest jednak jedynym możliwym zakończeniem postępowania mediacyjnego bowiem z jego wyniku strona może się wycofać lub zmodyfikować swoje żądanie, wniosek czy wniesiony przez siebie środek odwoławczy. Sprawa może zostać również załatwiona w drodze decyzji administracyjnej. Decyzja taka nie traci prawnego charakteru władczego rozstrzygnięcia, a jej wydanie po przeprowadzeniu mediacji może zdecydowanie zwiększyć akceptowalność rozstrzygnięcia przez stronę i zmniejszyć liczbę spraw skarżonych do sądu administracyjnego.

Równocześnie należy podkreślić, że charakter regulacji postępowania administracyjnego nie jest jednorodny. Przepisy dotyczące mediacji mają wymiar przepisów ius cogens. Problem dotyczy jednak braku precyzyjności kilku ważnych przepisów regulujących tę instytucję. W szczególności nie zostały doprecyzowane przesłanki dopuszczalności mediacji (art. 96a $\S 1$ K.p.a.), w tym okoliczności uzasadniające dokonanie czynności zawiadomienia stron o możliwości przeprowadzenia mediacji. Czynność ta formalnie inicjująca postępowanie mediacyjne może być podjęta zarówno z urzędu, jak na wniosek strony. Przepisy nie przesądzają jednak, czy wnioskiem strony organ jest związany, czy nie. Martyna Wilbrandt-Gotowicz wskazuje, że posłużenie się wyrażeniem „zawiadamia”, a nie „może zawiadomić” przemawia, co do zasady, za obligatoryjnym zawiadomieniem stron o możliwości przeprowadzenia mediacji $\mathrm{w}$ następstwie wniosku jednej ze stron. Jednak zasadnie zauważa, że organ nie ma kompetencji do sporządzenia takiego zawiadomienia, jeżeli w danej sprawie $\mathrm{w}$ istocie nie ma prawnych możliwości przeprowadzenia media$\mathrm{cji}^{4}$. Tym samym w praktyce to organ wydając zawiadomienie o możliwości przeprowadzenia mediacji będzie przesądzać o mediacyjnym charakterze sprawy, a tym samym sam decydować o możliwości zastosowania

43 Zob. M. Wilbrandt-Gotowicz, w: Komentarz zaktualizowany do Kodeksu postępowania administracyjnego, red. M. Jaśkowska, A. Wróbel, 2019 [baza danych LEX], Art. 96b. 
omawianej instytucji. W doktrynie postuluje się, aby wniosek o przeprowadzenie mediacji wiązał organ ${ }^{44}$, wychodząc z założenia, że ustawodawca kierował się $\mathrm{w}$ kwestii przeprowadzenia procedury mediacji zasadą dyspozycyjności stron, ograniczając arbitralność decyzją organu w tym przedmiocie. Złożenie przez jedną ze stron wniosku o przeprowadzenie mediacji wiąże zasadniczo organ co do obowiązku zawiadomienia pozostałych stron o możliwości jej przeprowadzenia (z wyjątkiem spraw, które nie odznaczają się zdolnością mediacyjną) ${ }^{45}$. Przemawia za tym brak rygoryzmu przesłanek przeprowadzenia mediacji, w tym niedookreśloność przesłanki charakteru sprawy, jak również konstrukcja omawianego przepisu. Ponadto ustawodawca nie określił formy działania organu w takim przypadku. Gdy przeprowadzenie mediacji zdaniem organu nie jest możliwe ze względu na charakter sprawy, odmowa zawiadomienia powinna przyjąć formę niezaskarżalnego zażaleniem postanowienia ${ }^{46}$. W praktyce brak precyzyjnej regulacji w tym zakresie może pozbawiać strony efektywnej ochrony prawnej. Pojawiają się bowiem skargi do sądu administracyjnego na czynność powiadomienia o braku zgody organu na przeprowadzenie mediacji, które są kwalifikowane jako niemieszczące się w ramach aktów lub czynności, o których mowa w art. 3 § 2 pkt 4 ustawy - Prawo o postępowaniu przed sądami administracyjnymi ${ }^{47}$, skutkując odrzuceniem skargi ze względu na brak właściwości sądu ${ }^{48}$. Podobnie dzieje się ze skargami na postanowienia organu w przedmiocie odmowy skierowania sprawy do mediacji jako niestanowiących postanowień podlegających zaskarżeniu na podstawie art. 3 § 2 pkt 2 ustawy - Prawo o postępowaniu przed sądami administracyjnymi ${ }^{49}$.

44 Zob. tamże; J. Wegner, w: Kodeks postępowania administracyjnego..., 2018 [baza danych LEX], Komentarz do art. $96 f$ K.p.a.

45 Zob. M. Wilbrandt-Gotowicz, w: Komentarz zaktualizowany do Kodeksu..., 2019 [baza danych LEX], Art. 96b.

46 Zob. tamże.

47 Ustawa z dnia 30 sierpnia 2002 r. - Prawo o postępowaniu przed sądami administracyjnymi, tekst jednolity: Dz. U. z 2019 r. poz. 2325.

48 Zob. postanowienie WSA w Warszawie z dnia 16 lutego 2018 r., IV SA/Wa 3178/17, http:/ / orzeczenia.nsa.gov.pl [dostęp: 28.10.2019 r.].

49 Postanowienie WSA w Łodzi z dnia 6 września 2018 r., II SA/Łd 514/18, http:/ / orzeczenia.nsa.gov.pl [dostęp: 28.10.2019 r.]; postanowienie WSA w Warszawie z dnia 12 września 2019 r., VI SA/Wa 643/19, http:/ / orzeczenia.nsa.gov.pl [dostęp: 28.10.2019 r.]. 
Ponadto wskazać należy na niedoprecyzowanie wymogu dotyczącego mediatora (posiadanie odpowiedniej wiedzy i umiejętności w zakresie prowadzenia mediacji w sprawach danego rodzaju - art. 96d § 2 K.p.a. ale już nie znajomości przepisów prawa w zakresie mediowanej sprawy). W praktyce oznaczać to może, że pomimo efektownego zakończenia mediacji - organ administracji publicznej nie załatwi sprawy zgodnie z ustaleniami zawartymi $\mathrm{w}$ protokole $\mathrm{z}$ przebiegu mediacji z powodu tego, że nie będą się one mieścić $\mathrm{w}$ granicach obowiązującego prawa. W związku z powyższym należy zauważyć, że strona pomimo wykorzystania tego narzędzia prawnego nie ma pewności, czy ustalenia z mediacji znajdą pełne odzwierciedlenie $w$ rozstrzygnięciu organu, a jedyną metodą weryfikacji będzie skorzystanie ze środków zaskarżenia czy, w dalszej kolejności, poddanie aktu wydanego przez organ sądowoadministracyjnej kontroli. Może to zniechęcać do wyboru tej drogi i wydłużać postępowanie. W tym kontekście z jednej strony ważnym jest wybór przez uczestników postępowania mediacyjnego mediatora, którego darzą zaufaniem, co może wpłynąć korzystnie na przebieg postępowania i jego efekty. Z drugiej strony, ważne są kwalifikacje mediatora, zwłaszcza zaś jego znajomość przepisów prawa w obszarze mediowanej sprawy zwiększająca szanse na uwzględnienie stanowiska ustalonego przez uczestników we władczym rozstrzygnięciu stanowiącym załatwienie sprawy lub w zatwierdzanej ugodzie. Wydaje się, że ze względu na efektywność postępowania administracyjnego należałoby te przepisy doprecyzować.

Jedną z przyczyn niewykorzystywania instytucji mediacji $\mathrm{w}$ postępowaniu administracyjnym mogą okazać się również koszty mediacji. Zgodnie z art. 961 K.p.a. mediatorowi przysługuje wynagrodzenie oraz zwrot poniesionych wydatków w związku z przeprowadzonym postępowaniem. Koszty te ponoszą: organ administracji publicznej w sprawach, w których organ będzie uczestnikiem mediacji; w sprawach, w których może być zawarta ugoda - strony w częściach równych, chyba że postanowią inaczej. Trudno w chwili obecnej prognozować, na ile koszty mediacji wpłyną na upowszechnienie się tej instytucji. Wydaje się natomiast, iż chętniej koszty te poniosą strony mające interes w ugodowym załatwieniu sprawy niż organ, który sam może daną sprawę załatwić - w drodze decyzji i bez dodatkowych kosztów.

Uregulowanie instytucji mediacji w K.p.a. niesie ze sobą wiele korzyści, tj. wzrost zaufania obywateli do organów administracji, pewne odciążenie sądownictwa administracyjnego, usprawnienie postępowania 
administracyjnego, skrócenie czasu jego trwania oraz zwiększenie wpływu stron postępowania na swoje sprawy. Ten cel jest jednak dalekosiężny. Aby go osiągnąć, potrzeba przede wszystkim proaktywnej postawy organu prowadzącego postępowanie. Niezbędna jest też zmiana mentalności administracji publicznej, gdzie mediacja nie ma tradycji. Powodzenie nowej instytucji w dużej mierze zależy bowiem od tego, czy organy faktycznie będą skłonne wypracowywać wraz obywatelami wspólne rozwiązania w każdej nadającej się do tego sprawie.

Słowa kluczowe: mediacja, postępowanie administracyjne, zasady mediacji

\section{Bibliografia}

\section{Źródła}

\section{Akty prawne}

Ustawa z dnia 14 czerwca 1960 r. - Kodeks postępowania administracyjnego, tekst jednolity: Dz. U. z 2020 r. poz. 256 z późn. zm.

Ustawa z dnia 30 sierpnia 2002 r. - Prawo o postępowaniu przed sądami administracyjnymi, tekst jednolity: Dz. U. z 2019 r. poz. 2325.

Council of Europe Committee of Ministers, Recommendation Rec2001(9) of the Committee of Ministers to member states on alternatives to litigation between administrative authorities and private parties (Adopted by the Committee of Ministers on 5 September 2001 at the $762^{\text {nd }}$ meeting of the Ministers' Deputies), https://search.coe.int/cm/Pages/result_details.aspx? ObjectId=09000016805e2b59 [dostęp: 15.09.2019 r.].

Rządowy projekt ustawy o zmianie ustawy - Kodeks postępowania administracyjnego oraz niektórych innych ustaw wraz z projektami aktów wykonawczych z dnia 28 grudnia 2016 r., Druk nr 1183, https://www.sejm.gov.pl/ Sejm8.nsf/druk.xsp?nr=1183 [dostęp: 15.09 .2019 r.].

\section{Orzecznictwo}

Postanowienie WSA w Warszawie z dnia 16 lutego 2018 r., IV SA/Wa 3178/17, http:/ / orzeczenia.nsa.gov.pl [dostęp: 28.10.2019 r.].

Wyrok WSA w Krakowie z dnia 26 kwietnia 2018 r., II SA/Kr 323/18, LEX nr 2471986.

Postanowienie WSA w Łodzi z dnia 6 września 2018 r., II SA/Łd 514/18, http:/ / orzeczenia.nsa.gov.pl [dostęp: 28.10.2019 r.]. 
Postanowienie WSA w Warszawie z dnia 12 września 2019 r., VI SA/Wa 643/19, http:/ / orzeczenia.nsa.gov.pl [dostęp: 28.10.2019 r.].

\section{Literatura}

Federczyk W., Mediacje w sferze działania władz publicznych - doświadczenia niemieckie, ADR Arbitraż i Mediacja 2012, nr 2.

Jakubowski A., w: Kodeks Postępowania Administracyjnego. Komentarz, red. M. Wierzbowski, A. Wiktorowska, wyd. 28, 2019 [baza danych Beck Online Komentarze], Art. 96 K.p.a.

Kędziora R., Kodeks postępowania administracyjnego. Komentarz, Warszawa 2017.

Kmieciak Z., Mediacja i koncyliacja w prawie administracyjnym, [Kraków] 2004.

Kmieciak Z., Problemy $i$ wyzwania partycypacji w postępowaniu administracyjnym, w: Partycypacja w postepowaniu administracyjnym. W kierunku uspołecznienia interesu prawnego, red. Z. Kmieciak, Warszawa 2017.

Kobylińska U., Innowacje w administracji publicznej w Polsce na poziomie samorządu lokalnego, Prace Naukowe Uniwersytetu Ekonomicznego we Wrocławiu 2015, nr 402: Polityka ekonomiczna.

Kocot-Łaszczyca A., G. Łaszczyca, Mediacja w ogólnym postępowaniu administracyjnym, Warszawa 2018.

Kodeks postępowania administracyjnego. Komentarz, red. W. Chróścielewski, Z. Kmieciak, 2018 [baza danych LEX].

Kodeks postepowania administracyjnego. Komentarz, red. A. Wróbel, M. Jaśkowska, Warszawa 2018.

Komentarz zaktualizowany do Kodeksu postepowania administracyjnego, red. M. Jaśkowska, A. Wróbel, 2019 [baza danych LEX].

Kulesza M., D. Sześciło, Polityka administracyjna i zarządzanie publiczne, Warszawa 2013.

Mediacja w sprawach administracyjnych, red. H. Machińska, Warszawa 2007.

Morawski L., Główne problemy wspótczesnej filozofii prawa. Prawo w toku przemian, Warszawa 2005.

Morek R., Dobrowolność mediacji i jej ograniczenia (prawo i praktyka), Studia Iuridica 2008 , t. 49.

Ostaszewski K., Partycypacja społeczna w procesie podejmowania rozstrzygnięć w administracji publicznej, Lublin 2013.

Prawo procesowe administracyjne, red. R. Hauser, Z. Niewiadomski, A. Wróbel, System Prawa Administracyjnego 9, Warszawa 2017.

Przybysz P., w: Kodeks postepowania administracyjnego. Komentarz, red. P. Przybysz, Warszawa 2017.

Sitek B., Jednostka wobec władztwa administracyjnego. Studium prawno-historyczno-porównawcze, w: Jednostka wobec działań administracji publicznej, red. E. Ura, E. Feret, S. Pieprzny, Rzeszów 2016. 
Stępień M., Janusowy charakter partycypacji w decydowaniu administracyjnym, w: Partycypacja w postępowaniu administracyjnym. W kierunku uspołecznienia interesu prawnego, red. Z. Kmieciak, Warszawa 2017.

Supernat J., Administracja publiczna, "governance" i nowe publiczne zarzadzanie, w: Prawna działalność instytucji społeczeństwa obywatelskiego, red. J. Blicharz, J. Boć, Wrocław 2009.

Tabernacka M., Mediacje w postępowaniu administracyjnym: uwarunkowania aksjologiczne i prakseologiczne, Kontrola Państwowa 2018, nr 3.

Waszkiewicz P., Zasady mediacji, w: Mediacje. Teoria i praktyka, red. E. Gmurzyńska, R. Morek, Warszawa 2009.

Wegner-Kowalska J., Idea mediacji w postępowaniu administracyjnym, Przegląd Prawa Publicznego 2016, nr 10.

Wegner-Kowalska J., Mediacja (art. 13, art. 96a-96g), w: Raport Zespołu Eksperckiego z prac w latach 2012-2016. Reforma prawa o postępowaniu administracyjnym, red. Z. Kmieciak, Warszawa 2017.

\section{EFFECTIVENESS OF MEDIATION IN ADMINISTRATIVE PROCEEDINGS}

\section{Sum mary}

The institution of administrative mediation is a legal instrument, i.e. a measure aimed at achieving the objective of amicable settlement of a case. This nature of mediation is highlighted by the standards of the Code of Administrative Procedure. This study explores an impact of the Code-based mediation on the effectiveness of administrative proceedings. In this context, effectiveness signifies the accomplishment of goals that underlay the incorporation of mediation into the Code of Administrative Procedure as pertinent to the basic principles of administrative proceedings. Those goals include: the promptness of proceedings, the principle of citizens' trust in the administrative authority and the principle of amicable dispute resolution. The article elaborates upon the following four issues: grounds for the incorporation of mediation into the Code of Administrative Procedure, the essence and principles of mediation, the application extent of mediation, conclusions on how the way mediation is governed affects the effectiveness of administrative proceedings.

Key words: mediation, administrative proceedings, rules of mediation 


\section{ЭФФЕКТИВНОСТЬ МЕДИАЦИИ В АДМИНИСТРАТИВНОМ ПРОИЗВОДСТВЕ}

\section{Резюме}

Институт медиации в административном вопросе является правовым инструментом, то есть средством достижения цели, каковой является мирное урегулирование дела.

Такой характер этого института подчеркивается нормами Административно-процессуального кодекса. Настоящее исследование показывает влияние медиативных норм в Административно-процессуальном кодексе на эффективность административного производства. Под эффективностью мы понимаем реализацию мотивов для введения медиации в Административно-процессуальный кодекс в связи с основными принципами административного производства, такими как время судопроизводства, принцип доверия граждан к органу и принципы мирного урегулирования споров.

В статье рассматриваются 4 вопроса: обоснование включения медиации в Административно-процессуальный кодекс, сущность и принципы медиации, область применения медиации, выводы относительно влияния метода регулирования института медиации на эффективность административного производства.

Ключевые слова: медиация, административное производство, принципы медиации 